\title{
ASSESSMENT OF THE ABILITY OF MANGROVES TO SERVE AS ACCUMULATED CARBON SINKS IN THE PLANTATIONS IN KIM DONG COMMUNE, KIM SON DISTRICT, NINH BINH PROVINCE, VIETNAM
}

\author{
Nguyen Thi Hong Hanh \\ Ha Noi University of Natural Resources and Environment
}

\begin{abstract}
Kim Dong is one of the three coastal communes in Kim Son District, Ninh Binh Province in the Red River Delta; Kim Dong is covered with 573.5 ha of mangrove plantations with dominant species of Kandelia obovata and Sonneratia caseolaris. The aim of this study is to assess the ability of mangroves to form carbon sinks in soil to support the state management of greenhouse gas emission reduction. The results are assumed to be used as a scientific basis and information for international negotiations on programs to cut greenhouse gas emissions, such as REDD and REDD ${ }^{+}$. For this purpose, we quantified the amount of carbon stored in the soil of Kandelia obovata mangroves aged 5, 4 and 3 years old in Kim Dong Commune, Kim Son District, Ninh Binh Province, Vietnam. The results showed that in K. obovata mangrove soil, carbon accumulation was age-dependent and the highest value was in the 5 year old one at 73.211 tons/ha. The annual cumulative carbon added to the mangrove soil (estimated by equivalent $\mathrm{CO}_{2}$ ) is also age-dependent and the 5-year-old mangroves accumulated the highest amount, 12.525 tons/ha/year (equivalent to 45.967 tons of $\mathrm{CO}_{2} / \mathrm{ha} /$ year). From our results, the ability of mangroves to accumulate carbon in the soil is high, and this fact serves a scientific basis to develop and implement projects of mangroves planting, combined with conservation, sustainable management and enhancement of carbon stocks of mangrove plantations in the coastal strips of Vietnam.
\end{abstract}

Keywords: Kandelia obovata, accumulated carbon, greenhouse gas, mangroves, REDD, REDD ${ }^{+}$.

Citation: Nguyen Thi Hong Hanh, 2016. Assessment of the ability of mangroves to serve as accumulated Carbon sinks in the plantations in Kim Dong Commune, Kim Son District, Ninh Binh Province, Vietnam. Tap chi Sinh hoc, 38(4): 521-527. DOI: 10.15625/0866-7160/v38n4.8895.

Corresponding author: honghanhsp@yahoo.com

Received 21 November 2016, accepted 26 December 2016

\section{INTRODUCTION}

Mangrove forests (mangroves) grow on marshy land flooded by saltwater in coastal estuarine areas, along the rivers and canals with brackish water due to daily tidal rise and receding. Mangroves have extremely important implications in economic terms, contributing greatly to the development of nature and society. Currently, the areas of mangroves in Vietnam and around the world tend to decline (Phan Nguyen Hong et al., 1997), and is considered as one of the causes of increasing greenhouse gas emissions and climate changes.

In order to find solutions for environmental protection, restoration and regeneration of the degraded natural ecosystems, especially of mangroves, and to contribute to reduce greenhouse gas emissions, Vietnam needs to join the REDD program (Reducing Emission from Deforestatian and Forest Degradation) and $\mathrm{REDD}^{+}$(later phase of REDD, developing countries should reduce the rate of deforestation and forest degradation in comparison with a reference period to receive financial support from developed countries). REDD and REDD ${ }^{+}$ operate to slow down the process of climate changes via financial support to developing countries for their stopping deforestation. Under this program, the countries will measure and monitor the $\mathrm{CO}_{2}$ emissions from deforestation and forest degradation within their country borders.

According to Intergovernmental Panel on Climate Change (IPCC, 2006), 5 carbon sinks were identified in forests: above ground 
biomass (AGB); below ground biomass (BGB), mainly found in forest tree roots; litter; dead wood (dead standing trees or fallen trees) and soil (soil organic carbon: SOC). To provide a basis for the evaluation of the role of coastal mangrove plantations in reducing greenhouse gases, responding to climate change, supporting state management of greenhouse gas emission reduction, the data of this study can be used as a scientific basis and information for international negotiations on programs to cut greenhouse gas emissions. Under this provision, we have conducted a study on the ability to form a carbon sink in the soil of planted mangroves in the coastal area of Kim Dong Commune, Kim Son District, Ninh Binh Province, Vietnam.

\section{MATERIALS AND METHODS}

\section{Study objects, site and time}

Research has been done on the Kandelia obovata mangroves planted on mud flats in 2008, 2009, and 2010 (5 year-old forest: R5T; 4 year-old forest: R4T; 3 year-old forest: R3T) in Kim Dong Commune, Kim Son District, Ninh Binh Province, Vietnam (figure 1).

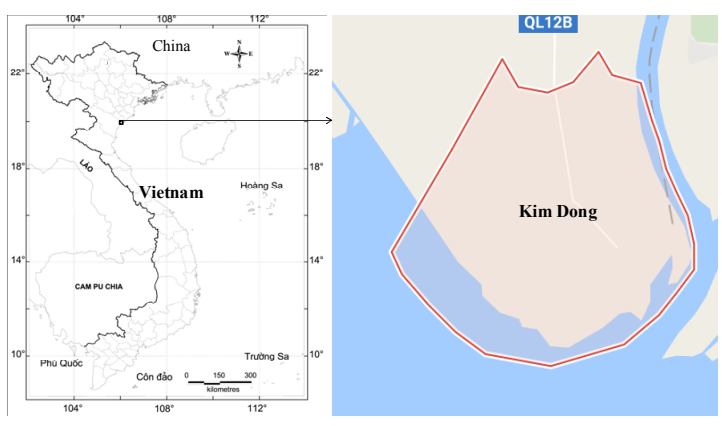

Figure 1. Study site

Kim Dong is one of three coastal communes of Kim Son District, Ninh Binh Province, belonging to the Red River Delta Biosphere Reserve; the commune has an area of about 600 ha of mangrove plantations of $K$. obovata and $S$. caseolaris with the dominance of $K$. obovata mangroves $(0.7 \times 0.7 \mathrm{~m})$, being planted along dykes and gradually expanding seaward. Kandelia obovata mangroves studied are at different ages of 5 (with $92 \%$ of closed canopy),
4 (approximately $90 \%$ of closed canopy) and 3 years (over $80 \%$ of closed canopy). 2016.

The study has been conducted from 2014 to

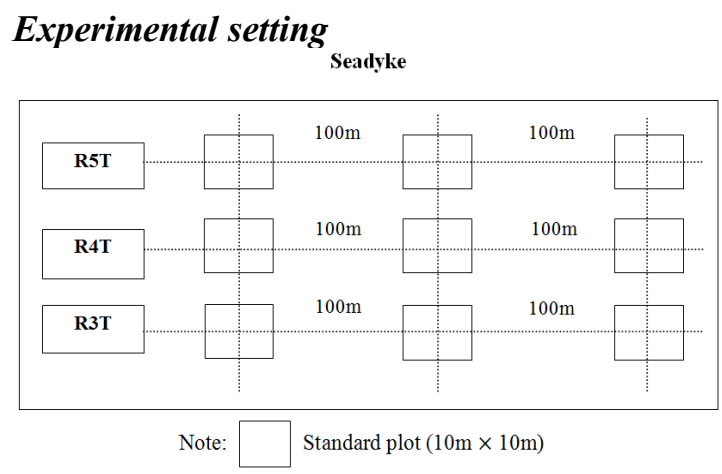

Figure 2. Experimental setting for soil sampling

The study site was from the dyke seaward in the direction perpendicular to the seadyke. Lying close to the seadyke is the 5 year-old $K$. obovata forest followed by the 4 year- and 3 year-old $K$. obovata forest in order. In the forest of each age, three sample plots of $100 \mathrm{~m}^{2}(10 \mathrm{~m}$ $\times 10 \mathrm{~m})$ in size each were set up; the distance between plots was $100 \mathrm{~m}$ in average (figure 2). For each forest age, three soil core samples were taken.

In order to compare the accumulated carbon in forest land and no-forest land, we took three soil core samples in the no-forest area near the 5 year-old forest

\section{Soil sampling}

A soil sampling auger was used to collect soil core samples from the surface layer to the depth of $100 \mathrm{~cm}$; tape measure was used and soil was sampled at different depths for analysis: $0-20 \mathrm{~cm}, 20-40 \mathrm{~cm}, 40-60 \mathrm{~cm}, 60-80$ $\mathrm{cm}$, and $80-100 \mathrm{~cm}$. After that, soil samples were brought to the environmental laboratory, Ha Noi University of Natural Resources and Environment to process for carbon analysis. The total number of soil samples for carbon analysis was 195 samples.

Organic carbon content (\%) in soil was determined using the method of Chiurin (Le Van Khoa et al., 2000). 


\section{Estimation of carbon accumulation in soil (ton/ha)}

Amount of carbon (carbon stock) in soil was determined based on the formula of Nguyen Thanh Ha (2004) and Kauffman \& Donato (2012).

$$
A(I I)=\sum_{0}^{H} a(h) x d h
$$

$$
a(h)=c(h) \times \frac{T(h)}{100}
$$$$
\mathrm{C}(\mathrm{H})=\mathrm{A}(\mathrm{H}) \times 10^{2}
$$

In this formula, $\mathrm{dh}[\mathrm{cm}]$ is the soil depth of a sample taken; $\mathrm{H}[\mathrm{cm}]$ is the depth of the experimental soil profile; $\mathrm{c}(\mathrm{h})[\%]$ is the carbon content at a depth of $\mathrm{h} ; \mathrm{T}(\mathrm{h})\left[\mathrm{g} / \mathrm{cm}^{3}\right]$ is bulk density (the proportion of the soil or soil weight to a soil volume) at a depth of $h ; a(h)\left[\mathrm{g} / \mathrm{cm}^{3}\right]$ is the accumulation of carbon in soil at a depth of $\mathrm{h} ; \mathrm{A}(\mathrm{H})\left[\mathrm{g} / \mathrm{cm}^{2}\right]$ is the accumulation of carbon in soil at a depth of $\mathrm{H} ; \mathrm{C}(\mathrm{H})$ [ton/ha] is the accumulation of carbon in forest soil at a depth of $\mathrm{H}$.

The total amount of $\mathrm{CO}_{2}$ absorbed was determined from the total amount of carbon (C) accumulated.
Total content of $\mathrm{CO}_{2}$ absorbed was determined by multiplying the total amount of accumulated carbon (C) with 3.67 (3.67 is a constant applied to all types of forests) (Kauffman J. B. et al., 2012).

\section{Calculation of the increment/decrement of carbon stock in mangrove soil}

We calculated the average increment or decrement of carbon stock in a period of time to assess the ability to create carbon sinks in the mangroves (IPCC, 2006).

$$
\Delta D=\frac{\Delta l_{2}-\Delta l_{1}}{t_{2}-t_{1}}
$$

Where, $\Delta \mathrm{B}$ : carbon credits for a period of time; $\Delta \mathrm{t}_{1}$ : carbon stock measured at time $\mathrm{t}_{1} ; \Delta \mathrm{t}_{2}$ : carbon stock measured at time $t_{2}$.

\section{RESULTS AND DISCUSSION}

\section{Carbon content (\%) in soil}

The carbon content $(\%)$ in the forest soil is expressed as the organic carbon content in 100 $\mathrm{g}$ of soil; this is an indicator to evaluate the total organic matter in mangrove soil. Carbon content $(\%)$ in the soil samples of $K$. obovata of 5, 4 and 3 year-old in relation to the soil depth are shown in table 1.

Table 1. Carbon content (\%) at different soil depths

\begin{tabular}{ccccc}
\hline \multirow{2}{*}{ Soil depths } & \multicolumn{4}{c}{ Carbon content in the soil samples (\%) } \\
\cline { 2 - 5 } & 5 year forest & 4 year forest & 3 year forest & Non-forest \\
\hline $0-20 \mathrm{~cm}$ & 0.80 & 0.73 & 0.70 & 0.50 \\
$20-40 \mathrm{~cm}$ & 0.73 & 0.67 & 0.68 & 0.47 \\
$40-60 \mathrm{~cm}$ & 0.61 & 0.60 & 0.59 & 0.39 \\
$60-80 \mathrm{~cm}$ & 0.54 & 0.55 & 0.52 & 0.36 \\
$80-100 \mathrm{~cm}$ & 0.47 & 0.48 & 0.46 & 0.33 \\
Mean & 0.63 & 0.61 & 0.59 & 0.41 \\
\hline
\end{tabular}

The carbon content $(\%)$ in soil increased with the forest age with the highest value in the 5 year-old forest (mean $0.63 \%$ ). The carbon content of non-forested soil was far lower than those of the forest soil.

Carbon content (\%) was reverseproportional to the soil depth; the carbon content was highest in the surface soil and decreased along with the depth regardless of the ages of the forest (table 1 and fig. 3).
At different forest ages, soil samples at 0-20 $\mathrm{cm}$ depth witnessed the highest carbon content (\%) $(0.70$ to $0.80 \%)$; decreasing carbon content was found at increasing soil depth. At a depth of $40-60 \mathrm{~cm}$, the carbon content in soil ranged from 0.59 to $0.61 \%$. At a depth of $80-100 \mathrm{~cm}$, the lower carbon content was observed at 0.46 to $0.48 \%$. Since mangrove soil in the study area is formed by alluvia mainly from the two rivers (Day River and Can River) and marine sediments 
carried by the tide, the organic matters in the sediments of mangroves are mainly from mangrove plants, tidal benthos, and partly the products of organic materials brought from the inland and planktonic organisms brought from the sea. Thus, organic matters are higher on the top surface and reduced along with the depth of the soil. Our results are consistent with the findings of Fujimoto et al (2000) in that the accumulated carbon content in the mangrove soils in Ca Mau and Can Gio in Southern Viet Nam. The authors stated that the accumulation of carbon in the soil was mainly observed at depths of 0-60 cm, gradually reducingat deeper layers.

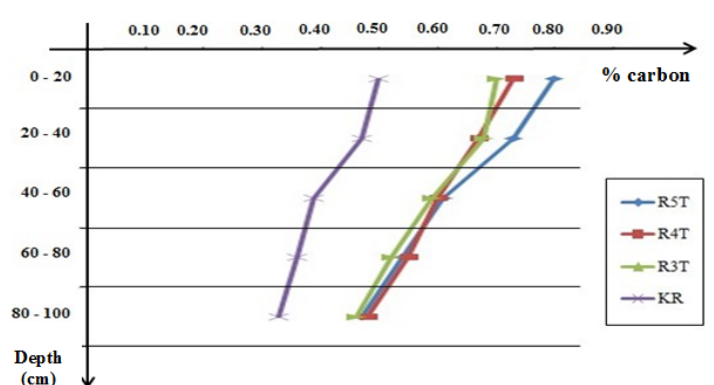

Figure 3. Carbon content $(\%)$ in forest soil at different depths

Table 2. Carbon stock (ton/ha) in relation to the mangrove tree ages and soil depths

\begin{tabular}{ccccc}
\hline \multirow{2}{*}{ Soil depth } & \multicolumn{4}{c}{ Carbon stock (ton/ha) } \\
\cline { 2 - 5 } & 5 year forest & 4 year forest & 3 year forest & Non-forest \\
\hline $0-20 \mathrm{~cm}$ & $19.471 \pm 2.132$ & $16.439 \pm 0.872$ & $14.685 \pm 1.329$ & $10.610 \pm 1.631$ \\
$20-40 \mathrm{~cm}$ & $17.604 \pm 1.362$ & $14.900 \pm 1.147$ & $13.685 \pm 0.784$ & $9.553 \pm 0.551$ \\
$40-60 \mathrm{~cm}$ & $14.814 \pm 1.035$ & $12.515 \pm 0.806$ & $11.748 \pm 1.092$ & $7.605 \pm 0.647$ \\
$60-80 \mathrm{~cm}$ & $11.780 \pm 0.639$ & $11.295 \pm 0.717$ & $10.750 \pm 0.645$ & $7.295 \pm 1.392$ \\
$80-100 \mathrm{~cm}$ & $9.542 \pm 0.652$ & $9.651 \pm 1.014$ & $8.343 \pm 0.672$ & $5.886 \pm 1.173$ \\
Total & $73.211 \pm 4.277$ & $64.800 \pm 3.065$ & $59.211 \pm 3.129$ & $40.950 \pm 2.098$ \\
\hline
\end{tabular}

Amount of carbon stock (ton/ha) in soil of the Kandelia obovata mangroves of various ages

The amount of carbon accumulated in Kandelia obovata forest of different ages at different soil depth are shown in table 2 .

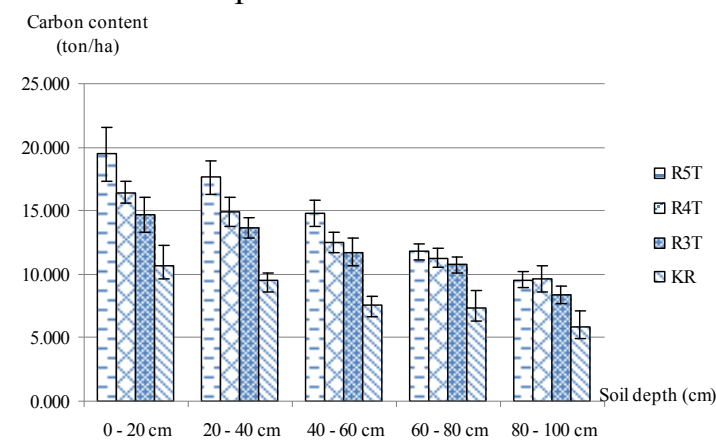

Figure 4. Carbon content (ton/ha) at different soil depths in the forest of various ages and nonforest areas

$\mathrm{R} 5 \mathrm{~T}=5$ year old forest; R4T $=4$ year old forest; $\mathrm{R} 3 \mathrm{~T}=3$ year old forest; KR: non-forest area.

As is expected from the data in Table 1 and Figure 3, carbon contents in the forest soil increased with the forest age but decreased with the soil depth. (table 2 and fig. 4). In the nonforest area, the variation of carbon contents at different depths of soil was rather small compared with the forest areas, suggesting that the litterfalls (branches, leaves, etc.) from mangrove trees and the roots of trees are an important sources of organic carbon in soil and therefore, enabling mangrove soil to be a carbon sink.

The total carbon accumulated in the soil of $0-100 \mathrm{~cm}$ depth in mangrove forests of various ages in Kim Dong increased with age from 59.211 tons/ha at 3 year-old to 73.211 tons/ha at 5 year-old. Carbon in the soil of bare land was about 40 tons/ha (fig. 5).

The high carbon content accumulated in mangrove soil is due to slow decomposition rate of organic matters (mainly roots) in soil. Albright (1976) reported that $90 \%$ of leaves were decomposed in nearly 7 months, but 50$88 \%$ of roots were retained for one year. Litterfall (leaves) are decomposed at a rapid rate or taken away by tide, but roots are decomposed slowly and accumulated for a long time. Thus, 
roots have an important role in the accumulation of carbon in mangrove soil.

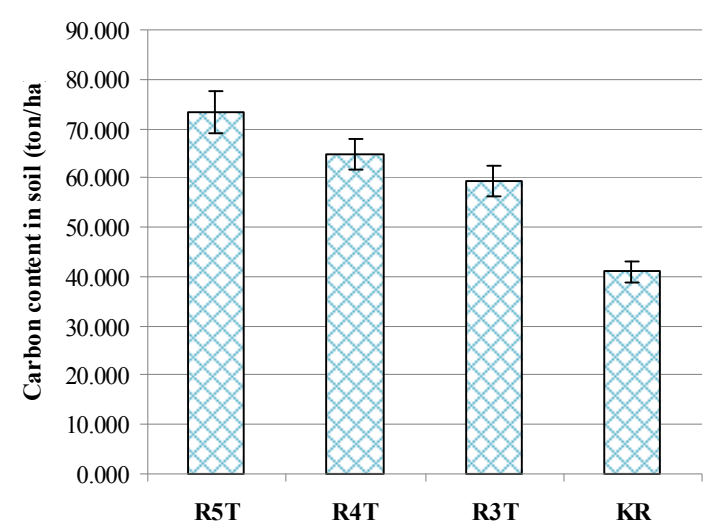

Figure 5. Total carbon (ton/ha) accumulated in soil at 0-100 cm depth in the 5, 4, and 3 yearold forests and in non-forest area

When the present results are compared with those of our previous study (Nguyen Thi Hong Hanh, 2014) on quantification of soil carbon in the Sonneratia caseolarisforest grown in Nam Hung Commune, Tien Hai District, Thai Binh province at the same age (4 years) of forest, the carbon content in the $K$. obovata forest in Kim Dong (64.800 tons/ha) in the present study was lower than that of $S$. caseolaris plantation in Nam Hung (85.800 tons/ha).

The accumulation of carbon in soil of $K$. obovata and $S$. caseolaris plantations in Northern Viet Nam is lower than that of the mangrove $R$. apiculata in Ca Mau and Can Gio,
Southern Vietnam (Fujimoto et al, 2000). The total carbon in Ca Mau mangrove soil at 0-100 $\mathrm{cm}$ depth ranged from 258.51 to 479.29 tons/ha, while the figure for Can Gio mangroves at 0 $\mathrm{cm}-100 \mathrm{~cm}$ depth varied from 245.20 to 309.90 tons/ha. this difference between north and south can be explained by the difference in climate of the study sites; the annual average air temperature in the south is $27.1^{\circ} \mathrm{C}$; and the month with the lowest average temperature is $25.2^{\circ} \mathrm{C}$, higher than the temperature in the North (annual average of $23^{\circ} \mathrm{C}-24^{\circ} \mathrm{C}$ ). Furthermore, the mangrove trees in Southern Vietnam are older than the $K$. obovata and $S$. caseolaris mangroves in the North. Wamer climate promotes the growth and development of forest trees.

From the above results and data analysis, accumulation of carbon in forest soil obiously depends not only on forest age, tidal innudation but also on plant species, density and natural conditions. In addition, the biological characteristics of the species is also one of the factors affecting the accumulation of carbon in forest soil.

\section{Assessment of the ability to form a carbon sink in mangrove soil}

Results on the changes of carbon stock in soil of pure Kandelia obovata mangroves aged 5,4 and 3 year-old in Kim Dong commune, Kim Son district, Ninh Binh province in 2014 and 2015 are presented in table 3.

Table 3. Carbon stock (ton/ha) at different soil depths in the forests of different ages in 2014 and 2015

\begin{tabular}{|c|c|c|c|c|c|c|c|}
\hline \multirow[b]{2}{*}{$\begin{array}{l}\text { Forest } \\
\text { age }\end{array}$} & \multirow[b]{2}{*}{ Time } & \multicolumn{5}{|c|}{ Carbon Stock (ton/ha) at different soil depths } & \multirow{2}{*}{$\begin{array}{c}\text { Total } \\
\text { carbon stock } \\
(0-100 \mathrm{~cm})\end{array}$} \\
\hline & & $0-20 \mathrm{~cm}$ & $\begin{array}{c}20-40 \\
\mathrm{~cm}\end{array}$ & $\begin{array}{c}40-60 \\
\mathrm{~cm}\end{array}$ & $\begin{array}{c}60-80 \\
\mathrm{~cm}\end{array}$ & $\begin{array}{c}80-100 \\
\mathrm{~cm}\end{array}$ & \\
\hline \multirow{2}{*}{5 year } & 2014 & 16.486 & 15.669 & 13.779 & 11.424 & 9.591 & 66.948 \\
\hline & 2015 & 22.457 & 19.539 & 15.849 & 12.136 & 9.493 & 79.473 \\
\hline \multirow{2}{*}{4 year } & 2014 & 15.541 & 13.832 & 11.599 & 10.490 & 8.864 & 60.326 \\
\hline & 2015 & 17.337 & 15.969 & 13.431 & 12.100 & 10.438 & 69.275 \\
\hline \multirow{2}{*}{3 year } & 2014 & 12.929 & 13.255 & 10.585 & 10.020 & 8.051 & 54.840 \\
\hline & 2015 & 16.441 & 14.114 & 12.912 & 11.480 & 8.636 & 63.583 \\
\hline
\end{tabular}


Table 4. Change in carbon stock in soil of 5, 4, and 3 year old $K$. obovata forests

\begin{tabular}{lcccccc}
\hline \multirow{2}{*}{ Time } & \multicolumn{5}{c}{ Carbon stock and corresponding $\mathrm{CO}_{2}$ absorbed by the forests (ton/ha) } \\
\cline { 2 - 7 } & \multicolumn{2}{c}{5 year old forest } & \multicolumn{2}{c}{ 4 year old forest } & \multicolumn{2}{c}{3 year old forest } \\
\cline { 2 - 7 } & $\begin{array}{c}\text { Accumulated } \\
\text { carbon }\end{array}$ & $\begin{array}{c}\text { Equivalent } \\
\mathrm{CO}_{2}\end{array}$ & $\begin{array}{c}\text { Accumulated } \\
\text { carbon }\end{array}$ & $\begin{array}{c}\text { Equivalent } \\
\mathrm{CO}_{2}\end{array}$ & $\begin{array}{c}\text { Accumulated } \\
\text { carbon }\end{array}$ & $\begin{array}{c}\text { Equivalen } \\
\mathrm{CO}_{2}\end{array}$ \\
\hline 2014 & 66.948 & 245.699 & 60.326 & 221.396 & 54.840 & 201.263 \\
\hline 2015 & 79.473 & 291.666 & 69.275 & 254.239 & 63.583 & 233.350 \\
\hline $\begin{array}{l}\text { Change in } \\
\text { carbon } \\
\text { content after } \\
\begin{array}{l}\text { one year } \\
\text { (ton/h/year) }\end{array}\end{array}$ & 12.525 & 45.967 & 8.948 & 32.839 & 8.743 & 32.087 \\
\hline
\end{tabular}

Based on the results of research in 2014 and 2015 on carbon accumulation in forest soil land, the number of carbon credits of the forest in a year was identified (table 4 ).

Results in Table 4 shows that, regardless of the ages of the forest and the depth of the soil, carbon accumulated in $K$. obovata plantation increased significantly after a year.

\section{CONCLUSION}

Carbon content (\%) in K. obovata mangrove soil in Kim Dong Commune, Kim Son District, Ninh Binh Province decreased with the increase of soil depth; the highest value was observed at the surface layer. The carbon content of the 5 year-old forest was $0.63 \%$ in average, followed by the 4 year-old $(0.61 \%)$ and 3 year-old $(0.59 \%)$ forests.

The total carbon accumulated in mangrove soil in Kim Dong Commune, Kim Son District, Ninh Binh Province increased with mangrove forest age; the 5 year-old mangroves had the highest value of 73.211 tons/ha followed by the 4 (64.800 tons/ha) and 3 (59.211 tons/ha) yearold mangroves.

Kandelia obovata mangroves was capable of accumulating carbon in soil. Every year, the total carbon cumulated in soil was equivalent to the amount of $\mathrm{CO}_{2}$ absorbed; the 5 year-old mangroves accumulated 12.525 tons of carbon/ha/year (equivalent to the $\mathrm{CO}_{2}$ absorbed of 45.967 tons/ha/year); the figure for the 4 year-old mangroves was 8.948 tons/ha/year (equivalent to the $\mathrm{CO}_{2}$ absorbed of 32.839 tons /ha/year) and the figure for the 3 year-old mangroves was 8.743 tons/ha/year (equivalent to the $\mathrm{CO}_{2}$ absorbed of 32.087 tons/ha/year).

The present results show that the ability of mangroves to accumulate carbon in the soil is high. This can be a scientific basis to develop and implement projects of mangroves planting combined with conservation, sustainable management and enhancement of carbon stocks of mangrove plantations in the coastal strips of Vietnam under programs to cut down on greenhouse gases for environmental protection and climate change response.

\section{REFERENCES}

Albright L. J., 1976. In situ degradation of mangrove tissues (Note), N. Z. Journal of Marine and Freshwater Research, 10: 385389.

Fujimoto K., Miyagi T., Adachi H., Murofushi T., Hiraide M., Kumada T., Tuan M. S., Phuong D. X., Nam V. N., Hong P. N., 2000. Belowground carbon sequestration of mangrove forests in Southern Vietnam, In: T. Miyagi (ed.) Organic material and sealevel change in mangrove habitat. Sendai, Japan, pp. 30-36.

Nguyen Thanh Ha, Ninomiya L., Toma T., Ogino K., 2002. Estimation of carbon accumulation in soil of mangrove forest in Thailand and Indonesia, In: Proceedings of the Ecotone X. Ecosystem valuation for assessing function goods and services of coastal Ecosystems in Southeast Asia. Agricultural Publishing House, Hanoi, pp. 173-194. 
Nguyen Thanh Ha, Yoneda R., Ninomiya I., Harada K., Tan D. V., Tuan M. S., Hong P. N., 2004. The effects of stand-age and inundation on the carbon accumulation in soil of mangrove plantation in Namdinh, northern Vietnam. The Japan Society of Tropical Ecology, 14: 21-37.

Nguyen Thi Hong Hanh, 2014. Quantitative study on carbon in soil of mangrove plantation in Nam Hung commune, TienHai district, Thai Binh province. Tap chi Sinh hoc, 36(1): 51-58. DOI: 10.15625/0866$7160 / \mathrm{v} 36 \mathrm{n} 1.4517$.

Phan Nguyen Hong (ed.), Tran Van Ba, Vien Ngoc Nam, Hoang Thi San, Le Thi Tre, Nguyen Hoang Tri, Mai Sy Tuan, Le Xuan Tuan, 1997. The role of mangroves in Vietnam, planting and caring techniques: 74-92. Agricultural Publishing House, Ha Noi.

IPCC, 2006. IPCC Guidelines for National
Greenhouse Gas Inventories, Prepared by National Greenhouse Gas Inventories Programme, Eggleston H.S., Buendia L., Miwa K., Ngara T., Tanabe K., (eds). Published: IGES, Japan.

Kauffman J. B., Donato D., 2012. Protocols for the measurement, monitorring and reporting of structure, biomass and carbon stocks in mangrove forests. Bogor, Indonesia: Center for International Forestry Research (CIFOR).

Le Van Khoa, Nguyen Xuan Cu, Bui Thi Ngoc Dung, Le Duc, Tran Khac Hiep, Cai Van Tranh, 2000. Methods of soil, water, fertilizer and plant analysis. Viet Nam Education Publishing House. pp.71-74.

Nguyen Hoang Tri, 2006. Economic valuation of mangrove ecosystem: theory and practice. National Economics University Publisher, pp. 11-34.

\title{
ĐÁNH GIÁ KHẢ NĂNG TẠO BỂ CHỨA CACBON TÍCH LŨY TRONG ĐẤT RÙ̉NG NGẬP MẬN TRỒNG TẠI XÃ KIM ĐÔNG, HUYÊN KIM SOON, TỈNH NINH BİNH, VIẸT NAM
}

\author{
Nguyễn Thị Hồng Hạnh \\ Trường Đại học Tài nguyên và Môi trường Hà Nội
}

\section{TÓM TẮT}

Xã Kim Đông, một trong 3 xã ven biển huyện Kim Sơn, tỉnh Ninh Bình, thuộc khu dự trữ sinh quyển đồng bằng Sông Hồng, với diện tích 573,5 ha rừng, ở đây, trang (Kandelia obovata) và bần chua (Sonneratia caseolaris) loài cây được trồng chủ yếu. Để đánh giá khả năng tạo bể chứa cacbon trong đất của rừng ngập mặn, làm cơ sở khoa học cho việc giám sát phát thải khí nhà kính và thông tin cho việc đàm phán quốc tế trong các chương trình thực hiện cắt giảm khí nhà kính như REDD và $R E D D^{+}$, bài báo này trình bày kết quả nghiên cứu định lượng cacbon tích lũy trong đất rừng trang (Kandelia obovata) 5 tuổi, 4 tuối và 3 tuối trồng ở địa điểm nghiên cứu nói trên. Kết quả nghiên cứu cho thấy, lượng cacbon tích lũy trong đất rừng trang (Kandelia obovata) đạt giá trị cao nhất ở rừng 5 tuổi với 73,211 tấn/ha; ở rừng 4 tuổi với 64,800 tấn/ha và thấp hơn là rừng 3 tuổi với 59,211 tấn/ha. Hàng năm, lượng lớn cacbon tích lũy thêm vào đất rừng ở rừng 5 tuổi 12,525 tấn/ha/năm (tương ứng với lượng $\mathrm{CO}_{2}$ là 45,967 tấn/ha/năm); rừng 4 tuổi là 8,948 tấn/ha/năm (tương ứng với lượng $\mathrm{CO}_{2}$ là 32,839 tấn/ha/năm); rừng 3 tuổi là 8,743 tấn/ha/năm (tương ứng với lượng $\mathrm{CO}_{2}$ là 32,087 tấn/ha/năm). Khả năng tích lũy cacbon trong đất rừng cao là cơ sở khoa học để xây dựng và thực hiện các dự án trồng rừng ngập mặn, kêt hợp với bảo tồn, quản lý bền vững và tăng cường trữ lượng cacbon rừng trồng ở các dải ven biển Việt Nam.

Tù khóa: Kandelia obovata, cacbon tích lũy, khí nhà kính, REDD, REDD ${ }^{+}$, rừng ngập mặn. 